\title{
Contrast enhancement of hypertrophic dura mater in MOG antibody-associated disease
}

Tatsuya Ueno, MD, PhD, Tomoya Kon, MD, PhD, Kimihiko Kaneko, MD, PhD, Toshiyuki Takahashi, MD, PhD, and Masahiko Tomiyama, MD, PhD

Neurology ${ }^{\circledR}$ 2019;93:271-272. doi:10.1212/WNL.0000000000007909

\section{Correspondence}

Dr. Ueno

tatsuya_ueno@

med.pref.aomori.jp

A 16-year-old boy with a history of optic neuritis and brainstem lesions due to myelin oligodendrocyte glycoprotein (MOG) antibody-associated disease complained of visual disturbance. He had no headache or other neurologic symptoms. Brain MRI showed contrast enhancement of hypertrophic dura mater in the posterior fossa (figure), but no abnormal dura elsewhere. Increasing prednisolone and adding tacrolimus following steroid pulse therapy improved the abnormality (figure). The clinical phenotype of MOG antibody-associated disease includes optic neuritis, myelitis, acute or multiphasic disseminated encephalomyelitis, and encephalitis. ${ }^{1}$ Although oligodendrocytes are not normally present in the dura matter, heterotopic neuroglial tissues were reported. ${ }^{2}$ The interactions of MOG antibody with heterotopic neuroglial tissue in the dura mater may contribute to the pathophysiology in this case.

Figure Post contrast-enhanced 3D fluid-attenuated inversion recovery images

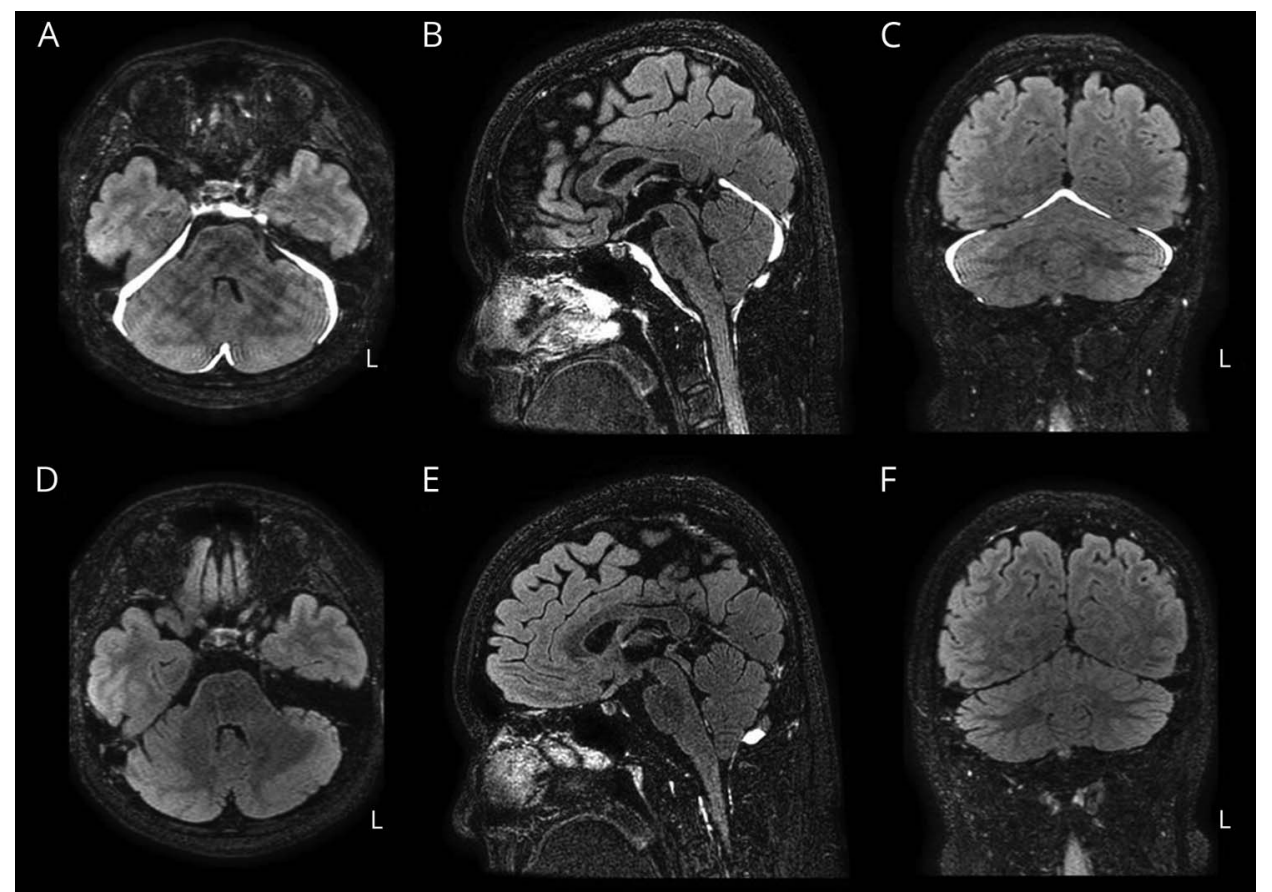

(A-C) Contrast enhancement of the hypertrophic dura mater at the time of the episode. (D-F) Disappearance of the abnormality after immunosuppressive therapies.

From the Department of Neurology (T.U., T.K., M.T.), Aomori Prefectural Central Hospital; Department of Neuropathology, Institute of Brain Science (T.K.), Hirosaki University Graduate School of Medicine, Aomori; Department of Neurology (K.K., T.T.), Tohoku University Graduate School of Medicine, Miyagi; Department of Neurology (K.K.), National Hospital Organization, Miyagi Hospital; and Department of Neurology (T.T.), National Hospital Organization, Yonezawa Hospital, Yamagata, Japan.

Go to Neurology.org/N for full disclosures. Funding information and disclosures deemed relevant by the authors, if any, are provided at the end of the article. 


\section{Acknowledgment}

The authors thank Ann Turnley, PhD, of Edanz Group (edanzediting.com/ac) for editing a draft of this manuscript.

\section{Study funding}

No targeted funding reported.

\section{Disclosure}

The authors report no disclosures relevant to the manuscript. Go to Neurology.org/N for full disclosures.

\section{Appendix Authors}

\begin{tabular}{|c|c|c|c|}
\hline Name & Location & Role & Contribution \\
\hline $\begin{array}{l}\text { Tatsuya } \\
\text { Ueno, MD, } \\
\text { PhD }\end{array}$ & $\begin{array}{l}\text { Aomori Prefectural } \\
\text { Central Hospital, } \\
\text { Japan }\end{array}$ & Author & $\begin{array}{l}\text { Designed and } \\
\text { conceptualized study, } \\
\text { analyzed the data, } \\
\text { drafted the } \\
\text { manuscript for } \\
\text { intellectual content }\end{array}$ \\
\hline $\begin{array}{l}\text { Tomoya } \\
\text { Kon, MD, } \\
\text { PhD }\end{array}$ & $\begin{array}{l}\text { Aomori Prefectural } \\
\text { Central Hospital; } \\
\text { Hirosaki University } \\
\text { Graduate School of } \\
\text { Medicine, Japan }\end{array}$ & Author & $\begin{array}{l}\text { Interpreted the data, } \\
\text { revised the } \\
\text { manuscript for } \\
\text { intellectual content }\end{array}$ \\
\hline
\end{tabular}

Appendix (continued)

\begin{tabular}{|c|c|c|c|}
\hline Name & Location & Role & Contribution \\
\hline $\begin{array}{l}\text { Kimihiko } \\
\text { Kaneko, } \\
\text { MD, PhD }\end{array}$ & $\begin{array}{l}\text { Tohoku University } \\
\text { Graduate School of } \\
\text { Medicine; National } \\
\text { Hospital } \\
\text { Organization, Miyagi } \\
\text { Hospital, Japan }\end{array}$ & Author & $\begin{array}{l}\text { Major role in the } \\
\text { acquisition of data, } \\
\text { revised the } \\
\text { manuscript for } \\
\text { intellectual content }\end{array}$ \\
\hline $\begin{array}{l}\text { Toshiyuki } \\
\text { Takahashi, } \\
\text { MD, PhD }\end{array}$ & $\begin{array}{l}\text { Tohoku University } \\
\text { Graduate School of } \\
\text { Medicine; National } \\
\text { Hospital } \\
\text { Organization, } \\
\text { Yonezawa Hospital, } \\
\text { Japan }\end{array}$ & Author & $\begin{array}{l}\text { Major role in the } \\
\text { acquisition of data, } \\
\text { revised the } \\
\text { manuscript for } \\
\text { intellectual content }\end{array}$ \\
\hline $\begin{array}{l}\text { Masahiko } \\
\text { Tomiyama, } \\
\text { MD, PhD }\end{array}$ & $\begin{array}{l}\text { Aomori Prefectural } \\
\text { Central Hospital, } \\
\text { Japan }\end{array}$ & Author & $\begin{array}{l}\text { Interpreted the data, } \\
\text { revised the } \\
\text { manuscript for } \\
\text { intellectual content }\end{array}$ \\
\hline
\end{tabular}

\section{References}

1. Reindl M, Waters P. Myelin oligodendrocyte glycoprotein antibodies in neurological disease. Nat Rev Neurol 2019; 15:89-102.

2. Ho KL. Heterotopic neuroglial tissue in the cerebral dura mater. Clin Neuropathol 1987;6:246-249.

\section{Committed to Making a Difference: 2020 American Academy of Neurology Research Program}

The American Academy of Neurology (AAN) is committed to making a profound difference in the lives of researchers, in turn making a difference in the lives of patients with brain disease. The ambitious 2020 AAN Research Program offers opportunities ranging from $\$ 130,000$ to $\$ 450,000$ and designed for all types of research across all career levels and discovery stages. Pave your own pathway to patient care by applying for one of the opportunities by the October 1, 2019, deadline.

Visit AAN.com/view/ResearchProgram today.

\section{The AAN Has Your Back!}

Every day, the AAN is fighting for you. From actively lobbying members of Congress for common sense legislation, to meeting with regulators to demonstrate the value of neurology and reduce regulatory hassles, the Academy is forcefully countering any threats to your profession and patient access to care. Learn more at AAN.com/policy-and-guidelines/advocacy, read the bimonthly Capitol Hill Report and monthly AANnews member magazine, and respond to Advocacy Action Alert emails when we invite you to share your voice with Congress.

Get into the conversation at \#AANAdvocacy. 


\section{Neurology}

\section{Contrast enhancement of hypertrophic dura mater in MOG antibody-associated disease}

Tatsuya Ueno, Tomoya Kon, Kimihiko Kaneko, et al. Neurology 2019;93;271-272

DOI 10.1212/WNL.0000000000007909

\section{This information is current as of August 5, 2019}

\section{Updated Information \&} Services

References

Subspecialty Collections

Permissions \& Licensing

Reprints including high resolution figures, can be found at: http://n.neurology.org/content/93/6/271.full

This article cites 2 articles, 0 of which you can access for free at: http://n.neurology.org/content/93/6/271.full\#ref-list-1

This article, along with others on similar topics, appears in the following collection(s):

Acute disseminated encephalomyelitis

http://n.neurology.org/cgi/collection/acute_disseminated_encephalomy elitis

All Demyelinating disease (CNS)

http://n.neurology.org/cgi/collection/all_demyelinating_disease_cns Autoimmune diseases

http://n.neurology.org/cgi/collection/autoimmune_diseases MRI

http://n.neurology.org/cgi/collection/mri

Optic neuritis; see Neuro-ophthalmology/Optic Nerve http://n.neurology.org/cgi/collection/optic_neuritis

Information about reproducing this article in parts (figures,tables) or in its entirety can be found online at:

http://www.neurology.org/about/about_the_journal\#permissions

Information about ordering reprints can be found online:

http://n.neurology.org/subscribers/advertise

Neurology ${ }^{\circledR}$ is the official journal of the American Academy of Neurology. Published continuously since 1951, it is now a weekly with 48 issues per year. Copyright () 2019 American Academy of Neurology. All rights reserved. Print ISSN: 0028-3878. Online ISSN: 1526-632X.

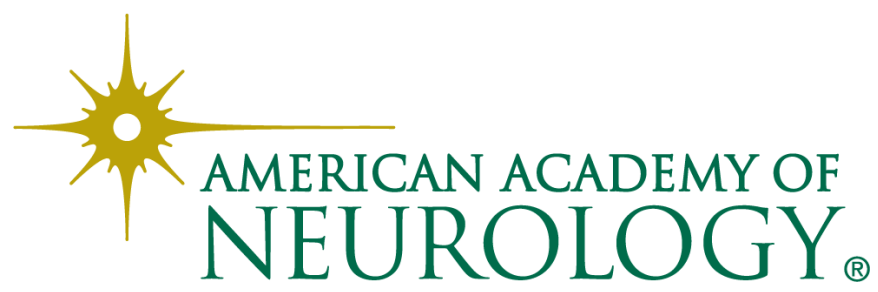

